\title{
Impact of post-harvest storage and freezing of palm fruits on the extraction yield and quality of African crude palm oil extracted in the laboratory
}

\author{
Doris Nanda $^{1,2}$, Germain Kansci ${ }^{2}$, Sylvain Rafflegeau ${ }^{3,4}$, Claire Bourlieu ${ }^{5}$, Georges Ngando Ebongue ${ }^{6}$ \\ and Claude Genot ${ }^{1, *}$ \\ 1 INRAE, UR BIA, 44316 Nantes, France \\ ${ }^{2}$ University of Yaoundé I, Department of Biochemistry, Yaoundé, Cameroon \\ ${ }^{3}$ CIRAD, UMR INNOVATION, F-34398 Montpellier, France \\ ${ }^{4}$ INNOVATION, Univ. Montpellier, CIRAD, INRAE, Institut Agro, Montpellier, France \\ 5 INRAE, CIRAD, Montpellier SupAgro, Univ Montpellier, UMR IATE, 34398 Montpellier, France \\ ${ }^{6}$ IRAD, CEREPAH, BP 243, Douala, Cameroon
}

Received 27 January 2020 - Accepted 1 September 2020

\begin{abstract}
In the frame of African artisanal small-scale extraction of palm oil, the effects of post-harvest storage time and freezing of palm fruits on the extraction yield and quality of crude palm oil (CPO) were studied at laboratory scale using a process mimicking artisanal extraction. The extraction yield and free fatty acid (FFA) content of CPO increased with the length of fruit storage time at room temperature and freezing. FFA, total fatty acid and triacylglycerol profiles indicated a lack of specificity of the lipases at work. During post-harvest storage, the carotenoid content of CPO decreased slightly, tocopherols and tocotrienols (tocols) remained steady, while lipid oxidation remained at a very low level. For frozen fruits, carotene and tocol contents decreased sharply as a function of storage time, thought remaining quite high, but decreasing amounts of secondary oxidation products were detected. The FFA content and lipid oxidation level were highly correlated, indicating a pro-oxidant effect of FFAs. To conclude, three days of storage prior to artisanal extraction seemed the best trade-off between extraction yield and CPO quality. Combined storage at room temperature and freezing of palm fruits led to a large range of FFA contents in CPO. Optimization of the FFA contents of artisanal CPOs in line with local consumer's demand calls for an assessment of their functional properties and sensory perception of foods formulated with CPOs.
\end{abstract}

Keywords: crude palm oil / extraction yield / post-harvest storage / freezing / lipolysis / oxidation

Résumé - Effet du stockage post-récolte et de la congélation des fruits de palme sur le rendement d'extraction et la qualité de l'huile de palme brute. Dans le contexte africain de l'extraction artisanale d'huile de palme brute (HPB), cette étude s'intéressait aux effets du stockage post-récolte et de la congélation des fruits du palmier sur le rendement d'extraction et la qualité des HPB. Les résultats confirment que rendement d'extraction et teneur en acides gras libres (AGL) des HPB augmentent avec la durée de stockage et la congélation. Le niveau maximal de lipolyse s'observe pour des fruits congelés 1 ou 3 jours après récolte. Les profils d'AGL, d'acides gras totaux et de triglycérides ne montrent pas de spécificité des lipases. Une diminution modérée de la teneur en caroténoïdes accompagnée de teneurs en tocophérols et tocotriénols (tocols) stables et de faibles niveaux d'oxydation sont observés lors du stockage. La congélation provoque une forte diminution des teneurs en caroténoïdes et tocols. Niveau d'oxydation et teneurs en AGL des HPB, très fortement corrélés, montrent l'effet pro-oxydant des AGL. Le stockage à température ambiante combiné à la congélation des fruits produit donc des HPB avec des teneurs en AGL très contrastées, trois jours de stockage semblant le meilleur compromis entre rendement d'extraction et qualité des HPB. L'optimisation pour des consommateurs locaux des teneurs en AGL des HPB artisanales nécessite l'évaluation de leurs propriétés fonctionnelles et de leur acceptabilité sensorielle.

Mots clés : huile de palme brute / extraction / stockage post-récolte / congélation / lipolyse / oxydation

\footnotetext{
*Correspondence: claude.genot@inrae.fr
} 


\section{Introduction}

Palm oil is extracted from the mesocarp of the oil palm fruit (Elaeis guineensis Jacq.). It is used in the manufacture of prepackaged foods, cosmetics, cleaning products, hair care products, soaps, personal care items and biofuel (Corley and Tinker, 2016).

African countries produce about $2 \mathrm{Mt}$ of palm oil/year, import about $8 \mathrm{Mt} /$ year and export less than $1 \mathrm{Mt} / \mathrm{year}$, including exports to other African countries (Oil world, 2018). Despite low land productivity ( $\mathrm{t}$ oil /ha), the African palm oil sector has been booming since the 1990s and it is currently expanding (Ordway et al., 2017, 2019). Factors limiting the land productivity of the African palm oil sector include the use of non-selected planting material (Cochard et al., 2001), poor agricultural management (Rafflegeau et al., 2010), harvest losses and low oil extraction rates in small-scale extraction units (Rafflegeau et al., 2018). The oil palm production boom is mainly driven by smallholders and smallscale, artisanal producers. It results from increasing local demand, combined with lower labour costs in Africa than in South-East Asia and Latin America. Local demand is characterized by the consumption by African populations of not only refined palm oil, like anywhere else in the world, but also, and to a large extent, of crude palm oil (CPO), locally called "red oil" or "huile rouge" (Cheyns and Rafflegeau, 2005). Locally produced CPO is a compulsory ingredient in several traditional recipes. According to Cheyns et al. (2006), palm oil consumption in Yaoundé reached $10 \mathrm{~kg} /$ person/year, $80 \%$ being CPO that accounts for about one third of total edible oil consumption (Rébéna et al., 2019).

CPO has valuable nutritional properties (Oguntibeju et al., 2009; Cassiday, 2017; Dong et al., 2017; Loganathan et al., 2017). It is a source of energy for the body with a high level of saturated fatty acids, mainly palmitic acid located in the $s n-1$ position, while its unsaturated oleic and linoleic acids are fully bioavailable, because they are in the $s n-2$ position (Hayes and Khosla, 2007; May and Nesaretnam, 2014). It also contains high concentrations of carotenoids (precursors of vitamin A) and tocopherol and tocotrienol isomers (vitamin E), thus helping to meet the populations' needs in these micronutrients. CPO found in the Cameroonian market place and obtained through artisanal extraction processes often contains high levels of FFA $(>10 \mathrm{wt} \%$ of total lipids, palmitic acid equivalent) (Kansci et al., 2003; Ngando Ebongue et al., 2011). In contrast, industrial CPO which is produced by industrial mills averages 3-4\% FFA and thus meets exportation standards (Gibon et al., 2007). The high FFA content of artisanal CPO, which is generally considered undesirable, contributes somewhat to $\mathrm{CPO}$ functional properties and to the original flavour expected from traditional African cuisine. Indeed, the FFA content is involved in the typical sensory properties of CPOs and CPO consumer preferences, as long as it is not too high (Cheyns et al., 2006; Poku, 2002). Although they have FFA contents higher than requested by international standards, artisanal crude palm oils are in line with local consumer standards for many recipes.

The presence of FFAs in CPO is mainly caused by the hydrolytic action of a mesocarp lipase (triacylglycerol acylhydrolase, EC 3.1.1.3) (Abigor et al., 1985; Henderson and Osborne, 1991; Ngando Ebongue et al., 2006; Morcillo et al., 2013). To a lesser extent, lipases from contaminating microorganisms (Eggins and Coursey, 1968; Hiol et al., 2000), such as Lactococcus and Leuconostoc (Tagoe et al., 2012), may also be involved in CPO lipolysis. All these lipases become activated when the palm fruit is bruised during harvesting, transportation and storage (Mohankumar et al., 1990; Chong and Sambanthamurthi, 1993). This also happens when cell membranes and oil bodies are damaged by chilling and/or freezing/thawing fruits. Indeed, the activity of lipases largely depends on the temperature, but the enzymes remain active at chilling or freezing temperatures (Sambanthamurthi et al., 1991; Cadena et al., 2013). The small-scale extraction process often involves storing bunches at the processing place after harvesting to facilitate not only fruit removal from the bunches, but also oil extraction, thus resulting in a higher oil extraction rate (Ngando Ebongue et al., 2011; Olalusi et al., 2017). However, it also leads to larger amounts of FFA in CPO (Poku, 2002; Domonhedo et al., 2018).

In a context of highly diverse extraction processes for artisanal CPO, consumers are looking for a better traceability and accurate quality indicators. For instance, it would be relevant to guarantee the nutritional quality and safety of CPOs containing high levels of FFA, but which meets consumer's expectations. This will mean being able to produce in the laboratory palm oils with a wide range of FFAs to further test their functionalities and acceptability for consumers.

In this aim, palm fruits were either stored at room temperature over various periods of time, or stored at room temperature and frozen/thawed prior to extraction. This study assessed the impact of such post-harvest treatments on CPO extraction yield and quality indicators, including free fatty acid content, total and free fatty acid composition, carotene, tocopherol and tocotrienol contents, and lipid oxidation. Freezing/thawing was considered as a way of maximising lipolysis and extending the range of FFA contents in the oils. The incidence of post-harvest treatments on the activity and specificity of lipases was also investigated.

\section{Material and methods}

\subsection{Planting material and experimental design}

The experimental design of the study is shown in Figure 1. Ripe fresh fruit bunches (FFB) were harvested from selected commercial oil palms (Elaeis guineensis of the tenera type, resulting from DELI $\times$ LA ME crosses) at IRAD specialized centre for oil palm research (CEREPAH), at La Dibamba, Cameroon. FFB were transported by car on the day of harvest to the laboratory located $225 \mathrm{~km}$ away from the collection point. The laboratory room temperature was $25-28^{\circ} \mathrm{C}$. Spikelets were removed from the bunch with a knife.

To assess the effects of the post-harvest storage of fruits at room temperature, and of freezing/thawing after that storage period, we carried out two sets of experiments.

In the first set, the effect of freezing/thawing on oil extraction yield and FFA content was assessed. Fruits from one single bunch were divided into 2 batches. The fruits of the first batch $(3 \times 500 \mathrm{~g})$ were extracted the day following harvesting. The fruits from the second batch $(3 \times 500 \mathrm{~g})$ were frozen the same day (AUCMA Chest Freezer, Model BD-105, 105 litres, Freezing capacity: $5 \mathrm{~kg} / 24 \mathrm{~h}$ ), kept at $-18^{\circ} \mathrm{C}$ for 3 days. The palm oil was extracted as described below. 


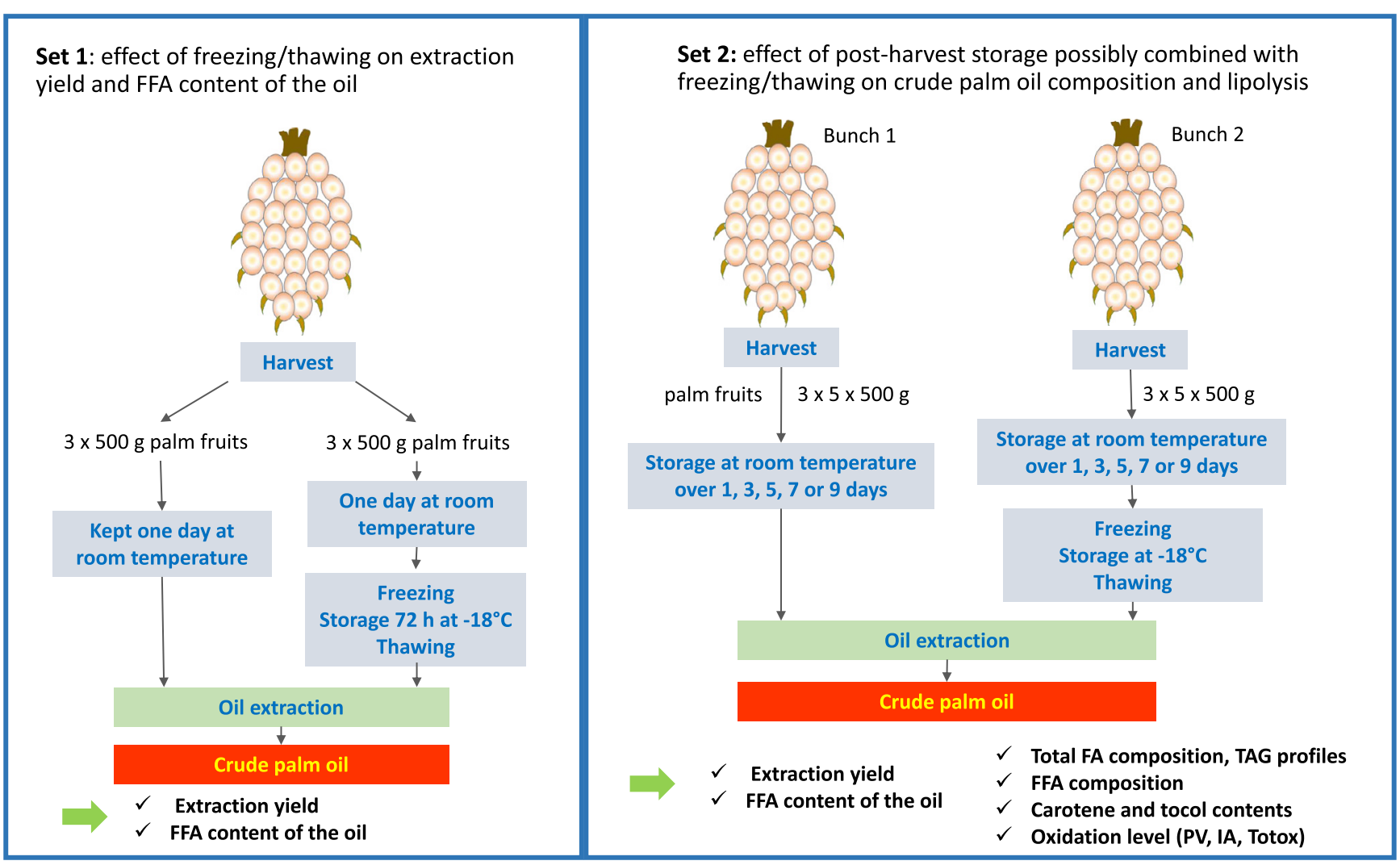

Fig. 1. Schematic representation of the experimental design.

A second set of experiments was implemented to gain more information on oil composition and on the lipolysis phenomenon occurring during post-harvest storage at room temperature, or induced by an additional fruit freezing/thawing cycle. The palm spikelets collected from one single bunch were kept at room temperature for $1,3,5,7$ or 9 days and the fruits were recovered by manual stripping from the spikelets. The fruits were then processed immediately after stripping. Fruits collected from another bunch were similarly kept at room temperature for $1,3,5,7$ or 9 days but then additionally frozen $\left(500 \mathrm{~g}\right.$ each sample) and stored at $-18 \pm 0.5^{\circ} \mathrm{C}$ for about 4 months. Lastly, frozen fruits were extracted as described below. The extracted oils were carefully recovered and stored in sealed glass flasks at $-18{ }^{\circ} \mathrm{C}$ until analysis.

\subsection{Crude palm oil extraction}

The raw or frozen fruits $(500 \mathrm{~g})$ were first steamed for two hours in a domestic pressure cooker, then mashed by hand in a mortar and the palm kernels discarded. The pulp, after reheating to $90^{\circ} \mathrm{C}$ in a pan, was processed with a small handscrew press (PITEBA, Scheemda, Netherlands) in order to recover the crude palm oil. To clarify the crude extract, 200 to $300 \mathrm{ml}$ of tap water was added and the mixture was heated until the upper oil phase became clear. The supernatant, namely the $\mathrm{CPO}$, was recovered by skimming with a tablespoon and weighed.

The whole extraction process was conducted in triplicate. Extraction yield was defined as the mean mass of $\mathrm{CPO}(\mathrm{g})$ per
$100 \mathrm{~g}$ of fruit. $\mathrm{CPO}$ was stored at $-18^{\circ} \mathrm{C}$ in brown glass bottles. Prior to analysis, the oil was heated above its melting point $\left(50^{\circ} \mathrm{C}\right)$ and thoroughly mixed for sampling.

The following variables were assessed throughout the present study: extraction yield and FFA content for samples for CPOs from sets 1 and 2, composition of the FFA fraction, total fatty acid composition, triacylglycerol composition, tocopherol and tocotrienol composition and contents, carotene content, peroxide value, anisidine value and TOTOX for the CPOs from set 2 (Fig. 1).

\subsection{CPO fatty acid composition}

Fatty acid methyl esters (FAME) were prepared according to the French standard NF T60-233 (Afnor, 1981b). Lipids $(20-30 \mathrm{mg}$ ) were diluted in $3 \mathrm{ml}$ of sodium methoxide $(0.05 \mathrm{M})$ containing two or three drops of phenolphthalein. The mixture was refluxed for $10 \mathrm{~min}$, then $3 \mathrm{ml}$ of methanol/acetyl chloride $(1: 1, \mathrm{v} / \mathrm{v})$ were added. The mixture was refluxed again for $10 \mathrm{~min}$, then cooled at room temperature. Ultrapure water $(10 \mathrm{ml})$ and hexane $(6 \mathrm{ml})$ were added. The upper organic phase containing FAMEs was finally recovered. FAMEs were analysed by gas chromatography with a Supelcowax 10 capillary column $(30 \mathrm{~m} \times 0.32 \mathrm{~mm} \times 0.250 \mu \mathrm{m}$, Merck $)$ and a flame ionization detector $\left(270^{\circ} \mathrm{C}\right)$. Helium was the carrier gas $\left(2 \mathrm{ml} \cdot \mathrm{min}^{-1}\right)$. The column temperature was maintained at $185^{\circ} \mathrm{C}$ for $2 \mathrm{~min}$, then raised at a rate of $4^{\circ} \mathrm{C} \mathrm{min}{ }^{-1}$ to $225^{\circ} \mathrm{C}$, and maintained at that temperature for $5 \mathrm{~min}$. The injector temperature was $250{ }^{\circ} \mathrm{C}$ in split mode $(1 / 100)$. The FAME 
peaks were identified by comparison of their retention times with those of standards. The results were expressed as a percentage of total identified fatty acids ( $\mathrm{g} / 100 \mathrm{~g}$ TFA).

\subsection{Free fatty acid content}

The acid value was determined by titration of an alcoholic solution of the oil samples by sodium hydroxide $(0.1 \mathrm{~N})$ with phenolphthalein as the indicator, according to standard NF T60-204 (Afnor, 1981a). The FFA content was expressed as equivalent palmitic acid $(\mathrm{g} / 100 \mathrm{~g}$ oil), the major fatty acid in palm oil.

\subsection{Fatty acid composition of FFAs}

FFAs were collected according to the method described by Alasnier et al. (2000). The oil, once diluted in acetone/ methanol $(1: 1 \mathrm{v} / \mathrm{v})$ in the presence of heptadecanoic acid as the internal standard (C17, Sigma-Aldrich $\geq 99 \%$, Switzerland), was mixed with an anion exchange resin (Amberlyst A26, Sigma, France), which bound FFAs. Glycerolipids were then washed from the resin with $5 \times 10 \mathrm{ml}$ acetone/methanol. FFAs were then methylated in the presence of the resin $\left(100^{\circ} \mathrm{C}\right.$, 2 min) with $14 \% \mathrm{BF}_{3} / \mathrm{CH}_{3} \mathrm{OH}$ (Morrison and Smith, 1964) and finally analysed and quantified by gas chromatography as FAMEs, as described by Kabri et al. (2013). Individual fatty acids were identified by comparison of retention times of samples with a standard FAME mix (cat 47885-U37, Supelco). Results were expressed as a percentage of each fatty acid to the total identified fatty acids, and as $\mathrm{mg} . \mathrm{g}^{-1}$ lipids.

\subsection{Analysis of triacylglycerol (TAG) composition by HPLC}

TAGs from crude palm oil samples were separated according to their equivalent carbon number $(\mathrm{ECN}=$ number of carbons on the fatty chain $-(2 \times$ number of double bonds $))$ by reverse phase liquid chromatography and detected with an evaporative light scattering detector (ELSD), as described by Fogang et al. (2017). The TAGs were identified by comparison of their retention times with those of a pure TAG standard (triolein, OOO, Saint-Quentin Fallavier, France) and with oils of known TAG composition. Quantification was achieved through calibration with triolein dissolved in chloroform/ methanol $1 / 1 ; \mathrm{V} / \mathrm{V})$. Concentrations were expressed as a percentage of total quantified TAGs.

\subsection{Evaluation of lipid oxidation}

The peroxide value (PV) (meq. active oxygen $/ \mathrm{kg}$ ) was determined by iodometric titration according to French Standard NF T60-220 (Afnor, 1981c). The anisidine value (AV) was determined by the ISO 6885 method (ISO, 2006). TOTOX $(=2 \mathrm{PV}+1 \mathrm{AV})$ was finally calculated.

\subsection{Determination of carotene content}

Carotene content was determined by visible spectrophotometry. The absorption spectra of CPOs dissolved in chloroform $\left(2.5 \mathrm{~g} . \mathrm{l}^{-1}\right)$ (chloroform, ethanol stab. for HPLC, Biosolve, Netherlands), were first recorded from 300 to
$600 \mathrm{~nm}$ against the solvent with a dual-beam spectrophotometer. Absorbance values were recorded at maximum wavelength $(464 \mathrm{~nm})$. Quantification was achieved using an external calibration curve ( 0.5 to $4 \mathrm{mg} . \mathrm{l}^{-1} ; 5$ concentrations) performed with an authentic $\beta$-carotene standard $(\beta$-carotene $\geq 97 \%$, BCBR8106V, Sigma-Aldrich, Switzerland). The analyses were carried out in triplicate and results were expressed as $\mu \mathrm{g} \beta$-carotene equivalent. $\mathrm{g}^{-1}$ lipids.

\subsection{HPLC analysis of tocopherols and tocotrienols}

Tocopherols and tocotrienols were analysed using the method described by Kabri et al. (2013) and Mba et al. (2018). These compounds were quantified in the lipid material previously solubilized in hexane $\left(20 \mathrm{mg} \cdot \mathrm{ml}^{-1}\right)$ through normal phase HPLC paired with a fluorescence detector and a silica column (Uptisphere strategy SI, $150 \times 4.6 \mathrm{~mm}$, granulometry: $2.2 \mu \mathrm{m}$, Interchim, Montluçon, France) maintained at $30^{\circ} \mathrm{C}$. Elution was carried out in isocratic mode with n-hexane/ ter-butylmethyl-ether $(90 / 10 ; \mathrm{v} / \mathrm{v})$ as the mobile phase $\left(1 \mathrm{ml} \cdot \mathrm{min}^{-1}\right)$. The excitation wavelength of the fluorescence detector was set at $295 \mathrm{~nm}$ and the emission wavelength at $330 \mathrm{~nm}$. Tocopherol and tocotrienol isomers were tentatively identified by comparing retention times with those of standard solutions of $\alpha, \beta, \gamma$ and $\delta$ tocopherols (tocopherol set 613424; Interchim, Montluçon, France) and $\gamma$-tocotrienol $(\gamma$-T3, ref 10008494; Interchim, Montluçon, France) and with data from the literature. Quantification was performed with calibration curves obtained from mixtures of the standards, with tocotrienols being quantified from the $\gamma$-T3 curve. The results, which were means of three measurements, were expressed as $\mu \mathrm{g} . \mathrm{g}^{-1}$ lipids.

\subsection{Statistical analyses}

Quantifications were carried out at least in duplicate. Oneway and two-way analyses of variance (ANOVA) and comparisons of means (Turkey's HSD test) were carried out at a threshold value of $0.05(p<0.05)$. The significance of Pearson's correlation coefficients was tested at a threshold value of 0.01 . Data were computed using XLSTAT software (XLSTAT Version 2013.2.04, Addinsoft ${ }^{\mathrm{TM}}$ ).

\section{Results and discussion}

\subsection{Storage at room temperature and fruit freezing enhance CPO extraction yield}

The first set of experiments was carried out on fruits from the same fruit bunch (Fig. 1). Results showed a better oil extraction yield for fruits that had been frozen and thawed before extraction than for fresh, unfrozen fruits: yields of $26.0 \pm$ $2.3 \mathrm{~g} / 100 \mathrm{~g}$ fruit, about $40 \mathrm{~g} / 100 \mathrm{~g}$ mesocarp were obtained from frozen/thawed fruits, as opposed to $20.0 \pm 0.5 \mathrm{~g} / 100 \mathrm{~g}$ fruit, i.e. $33 \mathrm{~g} / 100 \mathrm{~g}$ mesocarp from fresh fruits.

In our second set of experiments, the oil extraction yield increased from Day $1(15.0 \pm 0.6 \mathrm{~g} / 100 \mathrm{~g})$ to Day $9(28.7 \pm$ $1 \mathrm{~g} / 100 \mathrm{~g}$ ) of spikelet storage at room temperature. However, this increase in yield tended to level off between Day 7 (26.7 \pm $1 \mathrm{~g} / 100 \mathrm{~g})$ and Day $9(28.7 \pm 1 \mathrm{~g} / 100 \mathrm{~g})$ (Fig. 2A). The difference 


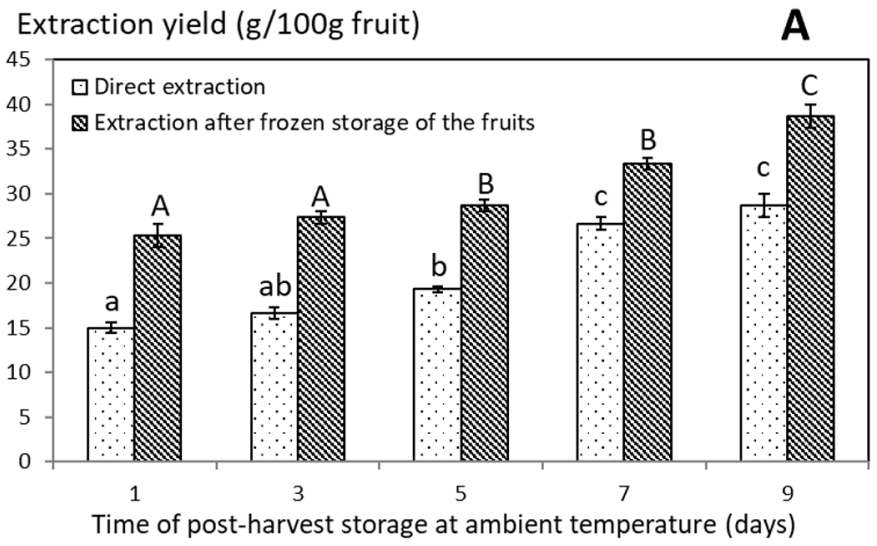

Free fatty acids (g/100g oil)

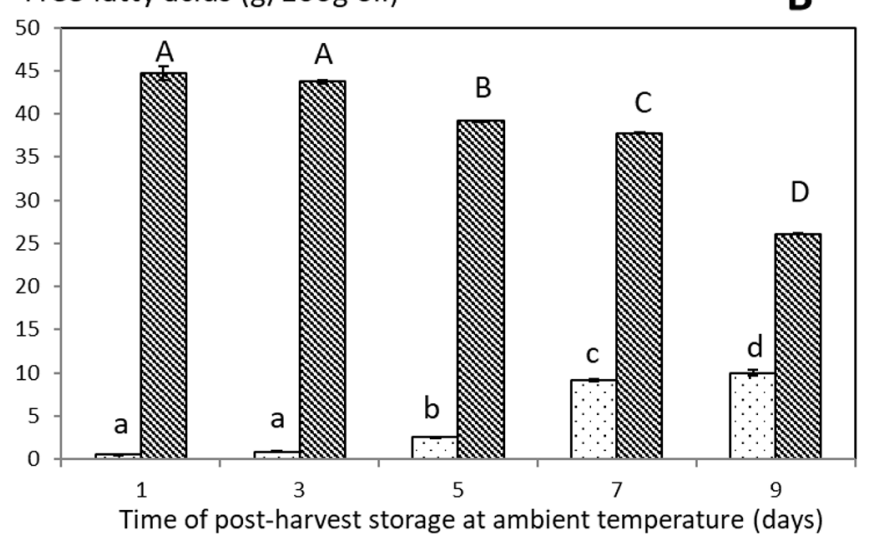

Fig. 2. Extraction yield (A; g oil $/ 100 \mathrm{~g}$ fruit) and free fatty acid content (B; g FFA/100 g oil) of crude palm oils extracted after fruit storage at room temperature, either directly or after a freezing period. In the same group, bars superscripted with different letters indicate significantly different means (Tukey's test; $p<0.05 ; n=3$ ). Error bars $=$ standard errors.

became significant $(p<0.05)$ after five days of storage. Thus, in agreement with usual artisanal practices, storing fruits and/or FFB at room temperature was found to facilitate CPO extraction. The yield for frozen/thawed fruits varied from $25.3 \pm 1.3 \mathrm{~g} / 100 \mathrm{~g}$ on Day 1 to $38.7 \pm 1.0 \mathrm{~g} / 100 \mathrm{~g}$ on Day 9, with the increase being significant $(p<0.05)$ from the fifth day of fruit storage at room temperature. In this set of experiments, oil extraction yield was found to be systematically around $10 \mathrm{~g}$ oil $/ 100 \mathrm{~g}$ fruit higher for frozen/thawed fruits than for their unfrozen counterparts, whatever the initial storage time at room temperature. These two sets of experiments indicated that the higher extraction yield that we recorded for frozen/thawed fruits was very likely mostly due to the breakdown of cell structures in the palm fruits induced by the growth of ice crystals. Oil extraction can also be facilitated by the enzymatic degradation of cell walls during freezing/ thawing. Indeed, Mohan and Mohankumar (2004) observed that the walls of mature palm mesocarp cells lost their integrity due to pectin solubilisation; the phenomenon was promoted by freezing. The physical rupture of oleosome membranes triggered by freezing/thawing enhances the release of endogenous lipids (Mohan and Mohankumar, 2004). Such mechanisms may explain why the highest yield was observed when storage of spikelets at room temperature (over 9 days) was combined with subsequent freezing/thawing of fruits. Additionally, as the fruits used for the second set of experiments were stored for 4 months in a frozen state, ice crystal growth during frozen storage could have caused further damage to the palm fruit cells and further enhanced the differences in extraction yields recorded between frozen and unfrozen fruits.

\subsection{Free fatty acid content in CPO increases with storage time at room temperature and fruit freezing/ thawing}

In the two sets of experiments, the FFA level was found to be lower than $1 \mathrm{~g} / 100 \mathrm{~g}$ oil when $\mathrm{CPO}$ was extracted from unfrozen fruits stored from three days onwards at room temperature. More precisely, in the first set of experiments, the FFA content reached $0.33 \pm 0.00 \mathrm{~g} \mathrm{C} 16 / 100 \mathrm{~g}$ oil after 1 day of fruit storage. In the second set, the FFA content was equal to $0.52 \pm 0.06 \mathrm{~g}$ and $0.87 \pm 0.04 \mathrm{C} 16 / 100 \mathrm{~g}$ oil after 1 and 3 days of fruit storage, respectively (Fig. 2B). It increased significantly $(p<0.05)$ after five days of fruit storage $(2.52 \pm 0.06 \mathrm{~g} / 100 \mathrm{~g}$ oil), reaching $9.97 \pm 0.32 \mathrm{~g} / 100 \mathrm{~g}$ oil on Day 9 .

FFA values were much higher in CPO extracted from frozen/thawed fruits: in crude palm oil obtained from fruits frozen 1 day after harvest, FFA content reached $30.4 \pm$ $2.1 \mathrm{~g} / 100 \mathrm{~g}$ oil in the first set of experiments and $44.75 \pm 0.80 \mathrm{~g} / 100 \mathrm{~g}$ oil in the second set. In the second set of experiments, the storage time at room temperature prior to freezing/thawing induced a gradual drop in FFA, which decreased to $26.08 \pm 0.05 \mathrm{~g} / 100 \mathrm{~g}$ oil on Day 9 (Fig. 2B). Thus, freezing/thawing triggered a boost in FFA content, and this boost was higher in freshly spiked fruits (an 86-fold FFA increase on Day 1) than in fruit stored at room temperature (only a 2.6-fold FFA increase on Day 9).

Such an increase in palm oil acidity during the post-harvest storage of fruits is well documented. For instance, palm oil originating from ripe bunches from genotypes with standard lipase activity which were heat-sterilized a few hours after harvest yielded around 0.3 to $0.7 \mathrm{~g}$ FFA $/ 100 \mathrm{~g}$ oil, while palm oil extracted from ripe bunches processed three days after harvest contained around 1.5\% FFA (Mohan and Mohankumar, 2004). FFA values were found to reach approximately $5 \%$ on Day 9 and $6 \%$ on Day 12 . In comparison, the average acidity of crude palm oil from industrial mills usually reaches 3-4\% (Mohan and Mohankumar, 2004; Gibon et al., 2007). Crude palm oil extracted from fallen and bruised fruits originating from low-lipase genotypes contained between 0.5 and $1.2 \%$, while that level ranged from 2 to $13 \%$ for fruits with high lipase activities (Ngando Ebongue et al., 2008). Interestingly, after a freezing/thawing cycle, the FFA content of oil extracted from high-lipase ripe fruits kept for $30 \mathrm{~min}$ at room temperature reached 17 to $55 \%$, while all low-lipase fruits contained less than 7.5\% FFA. Bruises on palm fruits caused by harvesting, transportation and handling of bunches, favour the activation of cell wall hydrolytic enzymes and the release of endogeneous lipids from oleosomes (Mohan and Mohankumar, 2004). They also allow the access of both endogenous and fungal lipases to triacylglycerols. Fruit storage then triggers the release of FFAs by lipases (Mohankumar et al., 1990; Morcillo et al., 2013). 
Table 1. Fatty acid composition of crude palm oil (TFA) extracted just after storage of the fruits at room temperature and free fatty acid (FFA) composition ( $\mathrm{g} / 100 \mathrm{~g}$ total identified fatty acids).

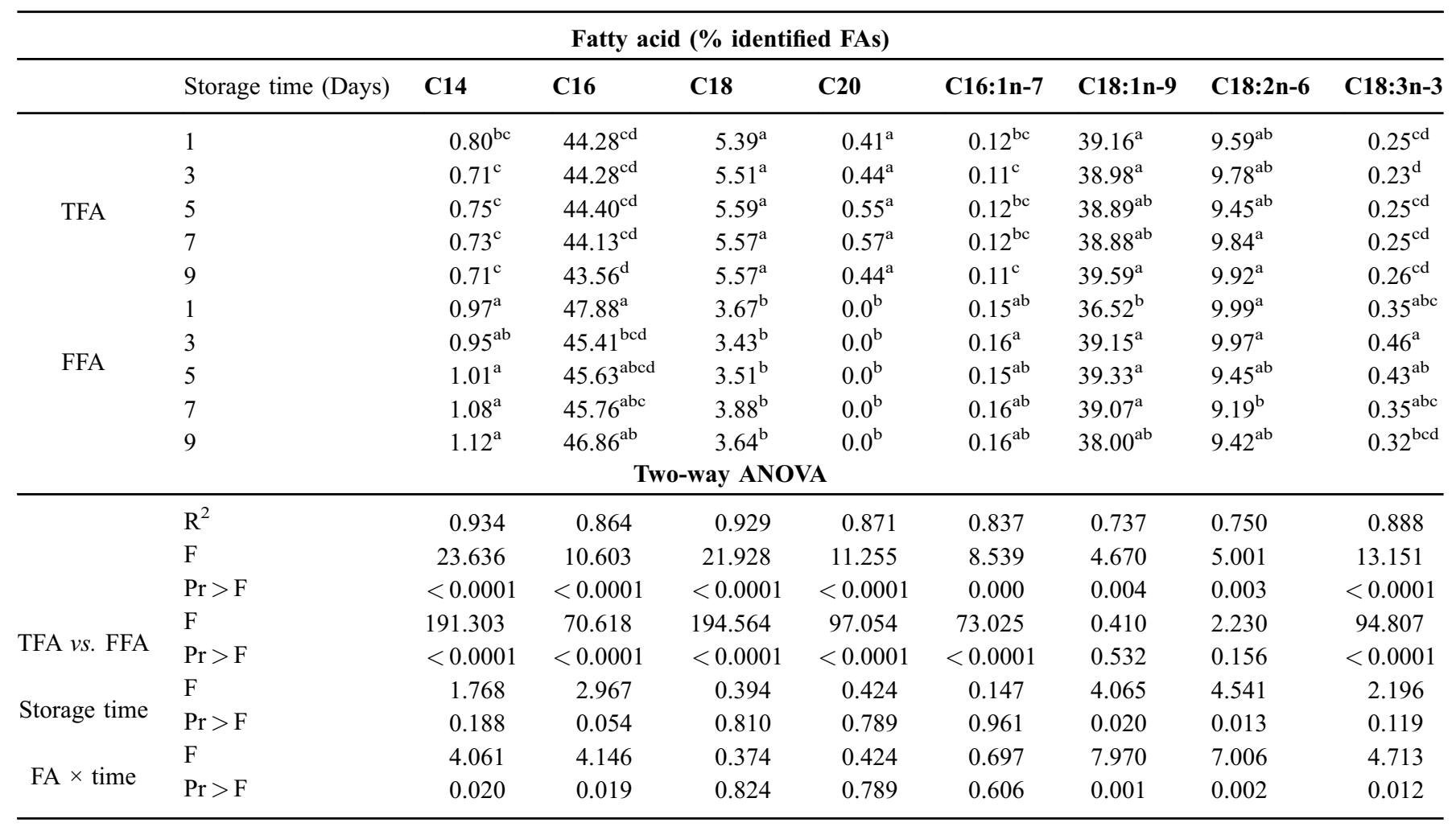

Results are means of triplicates for FA composition of the oil, and of a duplicate analysis for FA composition of the FFAs. Means with different letters in the same column differ significantly according to Tukey's test $(p<0.05)$.

Freezing/thawing affects FFAs in CPO, as it causes cell membrane breakage and the rupture of oleosomes due to the growth of ice crystals. This promotes TAG hydrolysis by mesocarp and fungal lipases. Lipolytic enzymes may continue to be slightly active at low temperatures and low water activities, and hydrolyse TAGs during frozen storage (Balls and Tucker, 1938; Sisla et al., 1997). This phenomenon has been observed for several microorganisms (Alford and Pierce, 1961). It is also considered as a limiting factor for preserving the sensory quality of frozen meat (Genot, 2000). After thawing, lipases recover their activities, at least partially. Palm mesocarp lipase remained active after freezing $\left(-17^{\circ} \mathrm{C}\right)$ of palm fruits (Henderson and Osborne, 1991). The lipolytic activity of extracts from palm mesocarp also recovered after fruit freezing, and remained stable for more than 5 weeks at $-20^{\circ} \mathrm{C}$ (Ngando Ebongue et al., 2006). In the present experiments, the FFA content of the oil extracted from frozen/ thawed fruits was found to decrease with the initial duration of fruit storage at room temperature. Such a drop might result from a gradual loss of lipase activity during storage at room temperature before stripping, due to inhibition by metabolites produced during cell wall disintegration and lipid hydrolysis and/or changes in the local environment of the lipases (including $\mathrm{pH}$ ) linked to cell catabolism. Similarly, (Tang et al., 2017) observed a loss of lipase activity when freezing palm fruits for 3 days at $-20^{\circ} \mathrm{C}$. According to these results, on Day 1 and Day 3, FFA contents in unfrozen fruits remained low, along with the associated $\mathrm{pH}$ decrease; this would have ensured high lipase activity during thawing. Conversely, on Day 5, and even more so on Day 7 and Day 9, the local FFA concentration was found to be high, and associated with a low local $\mathrm{pH}$, inducing a lower lipolysis rate during freezing/ thawing.

\subsection{Total fatty acid, free fatty acid and triacylglycerol compositions}

The fatty acid composition of CPO extracted during the second set of experiments (total fatty acids = TFA) and the fatty acid composition of the FFA fractions are shown in Table 1 (direct extraction from unfrozen fruits after storage at room temperature) and Table 2 (extraction after storage at room temperature and freezing/thawing of fruits). Table 3 indicates TAG compositions (percentages of main TAG molecular species) in CPO.

The TFA composition in oil extracted at different times after harvest (Tab. 1) were measured at ranges similar to those published by Lai et al. (2012), namely C14: 0.5-2\%; C16: 4048\%; C18: 3.5-6.5\%; C20: 0-1\%; C16:1: 0-0.6\%; C18:1 n-9: 30-44\%; C18:2 n-6: 6.5-12\%; C18:3 n-3: 0-0.5\%. Oils extracted from frozen fruits contained lower levels of palmitic acid $(\approx 35 \%)$ and higher levels of oleic acid $(\approx 51 \%)$ (Tab. 2$)$, although within ranges given by Montoya et al. (2014) (C16: $32.5-50 \%$ and $\mathrm{C} 18: 1: 35-50 \%$ ), for guineensis $\times$ oleifera hydrid palms. Interestingly, these authors found a highly significant negative correlation between palmitic and oleic 
Table 2. Fatty acid composition (TFA) of crude palm oils extracted after combined storage of the fruits at room temperature then freezing, and free fatty acid composition.

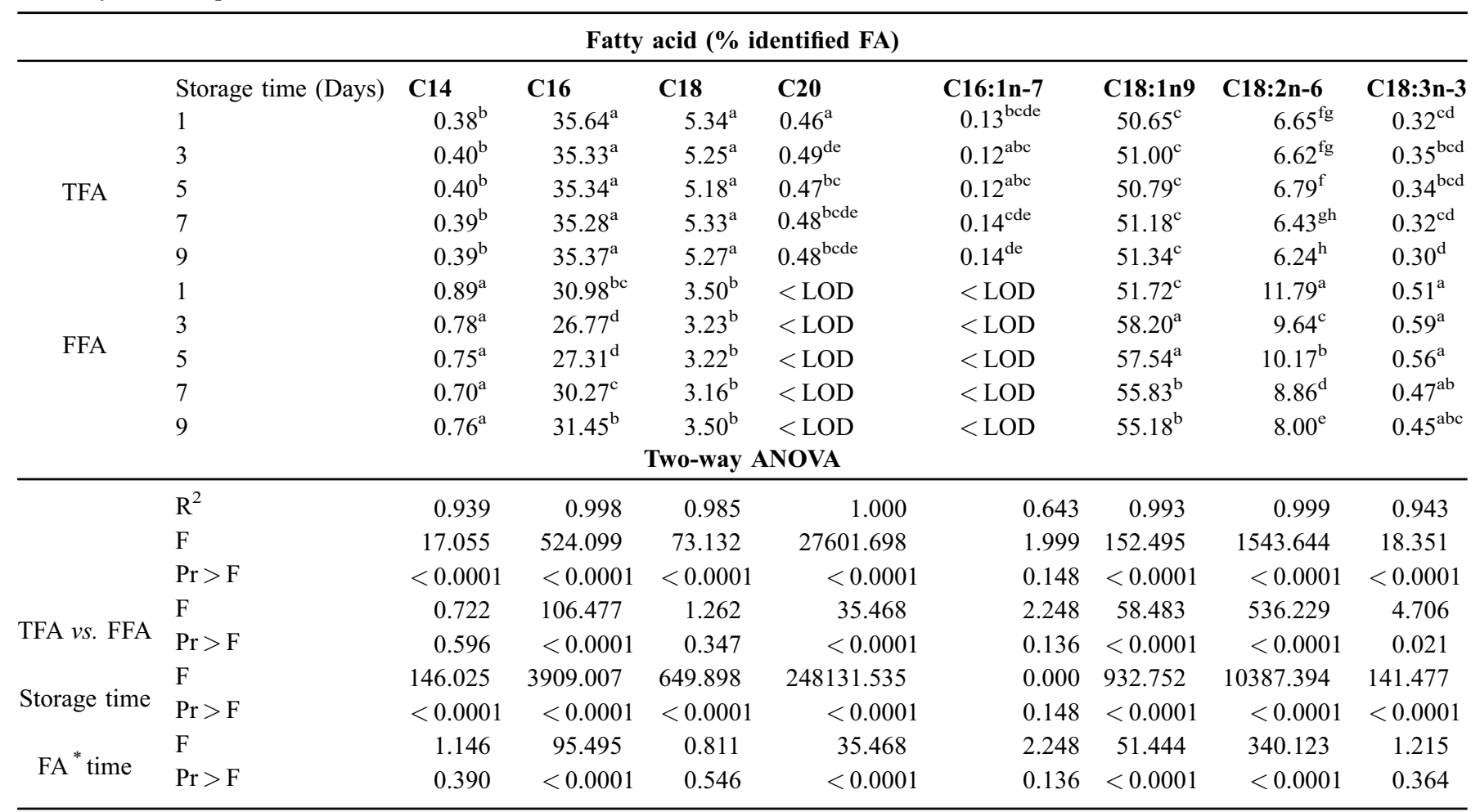

acid concentrations. These values were also within the ranges of palmitic and oleic acids measured in crude palm oils from Angola (C16: 29.8-48.6; C18:1: 30.7-50.2; Noh et al., 2002), from Ivory Coast (C16: 31-45; C18:1: 38.849.6; Monde et al., 2009) or Cameroon (C16: 35.7-42; C18:1: 39.8-47.8; Kansci et al., 2003). The TAG compositions of the oils extracted at different times after harvest (Tab. 3) closely fitted the compositions given by Lai et al. (2012) and Gee (2007). The TAG composition of frozen samples differed significantly but, as explained below, this was probably due to the high degree of lipolysis found in such oils. However, the oils obtained after direct extraction (unfrozen fruits) were found to be richer in saturated fatty acids (about $50 \mathrm{~g} / 100 \mathrm{~g}$ TFA, of which $44 \mathrm{~g} / 100 \mathrm{~g}$ palmitic acid, Tab. 1), than fruits processed after freezing/thawing (about $41 \mathrm{~g} / 100 \mathrm{~g}$ TFA, of which $35 \mathrm{~g} / 100 \mathrm{~g}$ palmitic acid) (Tab. 2). Such fruits exhibited a lower percentage of unsaturated fatty acids, mainly oleic acid: $39 \mathrm{~g} / 100 \mathrm{~g}$ vs $51 \mathrm{~g} / 100 \mathrm{~g}$ TFA for CPO obtained after freezing, and more linoleic acid (about 9.5 vs $6.6 \mathrm{~g} / 100 \mathrm{~g}$ TFA). They also contained less POO, PPO, PPP, PPO, PPS and SSO (P: palmitic acid (16:0); S: stearic acid (18:0); O: oleic acid (18:1 n-9)) and more of the TAG species containing linoleic acid (PLL, OOL, POL) than the CPOs from frozen fruits (Tab. 3). The palm fruits used for the assessment of the two storage methods originated from two different fruit bunches which were harvested from two oil palms, both of descendants of selected commercial planting material. Such differences in fatty acid compositions in oils from frozen and unfrozen samples were probably due to the genetic variability existing among selected commercial planting material.

Differences in TFA and FFA compositions (Tabs. 1 and 2), and changes in TAG distribution (Tab. 3) can provide an indication of lipolysis selectivity.

When crude palm oil was extracted directly after storing fruits at room temperature, the storage time did not significantly change the TFA and FFA compositions (ANOVA, $p>0.05$ ) (Tab. 1). The only significant, but marginal, effects of storage time were observed for oleic $(p=0.020: 36.5 \mathrm{~g} / 100 \mathrm{~g}$ in FFA on D1 as opposed to $38-39 \mathrm{~g} / 100 \mathrm{~g}$ for other conditions) and linoleic acid $(p=0.013)$. At the same time, the TAG composition showed only slight changes, with significant (Tukey's test $p<0.05$ ), but very limited effects, of storage time for PLL (1.7 to $1.5 \%$ total TAGs), PPO (28.4 to $29.7 \%$ total TAGs) and SOO (3.9 to 3.6\%) (Tab. 3). The FA compositions for TFA and FFA also showed significant, but very modest (always less than 3.5\%), differences for most FAs (two-way ANOVA; $p<0.0001$ for C14, C16, C18, C20, C16:1n-7 and C18:3n-3). This indicated a very limited selective release of FFAs from the TAGs, if at all, during palm fruit storage at room temperature.

When extraction was carried out after fruit freezing/ thawing, the storage time at room temperature did not affect the TFA distribution (Tab. 2). Only linoleic acid showed a minor, but significant, decrease on Day $9(6.24 \pm 0.01 \mathrm{~g} / 100 \mathrm{~g})$ as compared to Day 1, Day 3 and Day $5(6.65$ to $6.79 \mathrm{~g} / 100 \mathrm{~g})$ (Tukey's test, $p<0.05$ ) (Tab. 2). The fatty acid composition of the FFAs differed significantly from the total fatty acid composition with higher percentages of oleic (mean values 
Table 3. Triacylglycerol composition of crude palm oils extracted just after storage of the fruits at room temperature, and after combined storage at room temperature then freezing.

\begin{tabular}{|c|c|c|c|c|c|c|c|c|c|c|c|c|c|}
\hline & & & Triacy & lycero & $(w t \% o$ & otal ident & ed and & Iantified & AGs) & & & & \\
\hline $\begin{array}{l}\text { Storage } \\
\text { time (days) }\end{array}$ & \multicolumn{13}{|c|}{ CPO extracted directly after storage at room temperature } \\
\hline 1 & $1.7^{\mathrm{ab}}$ & $1.8^{\mathrm{a}}$ & $10.5^{\mathrm{a}}$ & $8.1^{\mathrm{a}}$ & $4.8^{\mathrm{a}}$ & $1.9 \mathrm{a}$ & $25.2^{\mathrm{a}}$ & $28.5^{\mathrm{a}}$ & $3.7^{\mathrm{a}}$ & $3.9^{\mathrm{b}}$ & $8.9^{\mathrm{a}}$ & $1.0^{\mathrm{a}}$ & $0.82^{\mathrm{b}}$ \\
\hline 3 & $1.8^{\mathrm{b}}$ & $1.9^{\mathrm{a}}$ & $11.1^{\mathrm{a}}$ & $8.2^{\mathrm{a}}$ & $4.5^{\mathrm{a}}$ & $1.5 \mathrm{a}$ & $25.1^{\mathrm{a}}$ & $28.7^{\mathrm{a}}$ & $3.6^{\mathrm{a}}$ & $3.8^{\mathrm{ab}}$ & $8.1^{\mathrm{a}}$ & $1.0^{\mathrm{a}}$ & $0.83^{\mathrm{b}}$ \\
\hline \multirow[t]{2}{*}{9} & $1.5^{\mathrm{a}}$ & $1.6^{\mathrm{a}}$ & $10.4^{\mathrm{a}}$ & $7.5^{\mathrm{a}}$ & $5.3^{\mathrm{a}}$ & $1.7 \mathrm{a}$ & $25.5^{\mathrm{a}}$ & $29.7^{\mathrm{c}}$ & 3. $5^{\mathrm{a}}$ & $3.6^{\mathrm{a}}$ & $8.1^{\mathrm{a}}$ & $0.9^{\mathrm{a}}$ & $0.83^{\mathrm{b}}$ \\
\hline & \multicolumn{13}{|c|}{ CPO extracted after combined storage at room temperature then freezing } \\
\hline 1 & $<\mathrm{LOD}$ & $<$ LOD & $2.6^{\mathrm{a}}$ & $5.3^{\mathrm{c}}$ & $0.0^{\mathrm{a}}$ & $<\mathrm{LOD}$ & $23.4^{\mathrm{a}}$ & $44.5^{\mathrm{e}}$ & $8.0^{\mathrm{d}}$ & $1.4^{\mathrm{a}}$ & $11.9^{\mathrm{c}}$ & $1.8^{\mathrm{c}}$ & $1.2^{\mathrm{b}}$ \\
\hline 3 & $<$ LOD & $<$ LOD & $3.5^{\mathrm{b}}$ & $3.9^{\mathrm{b}}$ & $0.0^{\mathrm{a}}$ & $<$ LOD & $31.0^{\mathrm{b}}$ & $39.6^{\mathrm{d}}$ & $5.2^{\mathrm{c}}$ & $2.4^{\mathrm{b}}$ & $11.8^{\mathrm{b}}$ & 1. $3^{\mathrm{b}}$ & $1.3^{\mathrm{c}}$ \\
\hline 5 & $<\mathrm{LOD}$ & $<$ LOD & $4.5^{\mathrm{c}}$ & $3.9^{\mathrm{b}}$ & $2.6^{\mathrm{b}}$ & $<\mathrm{LOD}$ & $31.4^{\mathrm{b}}$ & $36.8^{\mathrm{c}}$ & $4.5^{\mathrm{b}}$ & $3.1^{\mathrm{c}}$ & $10.8^{\mathrm{b}}$ & $1.2^{\mathrm{b}}$ & $1.1^{\mathrm{b}}$ \\
\hline
\end{tabular}

Table 4. Effect of palm fruit storage at room temperature on lipid oxidation in CPO extracted immediately, or after further frozen storage of palm fruits.

\begin{tabular}{|c|c|c|c|c|c|c|}
\hline \multirow{2}{*}{$\begin{array}{l}\text { Days of storage } \\
\text { before stripping }\end{array}$} & \multicolumn{3}{|c|}{ Direct extraction } & \multicolumn{3}{|c|}{ Extraction after frozen storage } \\
\hline & Peroxide value & Anisidine value & TOTOX & Peroxide value & Anisidine value & TOTOX \\
\hline 3 & $0.0 \pm 0.00^{\mathrm{a}}$ & $0.87 \pm 0.00^{\mathrm{a}}$ & 0.9 & $2.16 \pm 0.10^{\mathrm{a}}$ & $43.76 \pm 0.10^{\mathrm{b}}$ & 48.1 \\
\hline 5 & $0.47 \pm 0.03^{\mathrm{b}}$ & $2.52 \pm 0.03^{\mathrm{b}}$ & 3.5 & $1.79 \pm 0.09^{\mathrm{ab}}$ & $39.15 \pm 0.09^{c}$ & 42.9 \\
\hline
\end{tabular}

Results are expressed as mean \pm standard deviation $(n=3)$. TOTOX $=2$ peroxide +1 anisidine value. Means with different letters in the same column differ significantly by Tukey's test $(p<0.05)$.

\pm standard error for FFA: $55.69 \pm 0.11 \mathrm{~g} / 100 \mathrm{~g}$ and for TFA: $50.99 \pm 0.11 \mathrm{~g} / 100 \mathrm{~g}$ ), linoleic (FFA: $9.69 \pm 0.02 \mathrm{~g} / 100 \mathrm{~g}$; TFA: $6.55 \pm 0.02 \mathrm{~g} / 100 \mathrm{~g}$ ) and linolenic (FFA: $0.51 \pm 0.01 \mathrm{~g} / 100 \mathrm{~g}$; TFA: $0.33 \pm 0.01 \mathrm{~g} / 100 \mathrm{~g}$ ) acids balanced by lower percentages of palmitic (FFA: $29.35 \pm 0.07 \mathrm{~g} / 100 \mathrm{~g}$; TFA: $35.39 \pm$ $0.07 \mathrm{~g} / 100 \mathrm{~g}$ ) and stearic (FFA: $3.32 \pm 0.054 \mathrm{~g} / 100 \mathrm{~g}$; TFA: $5.27 \pm 0.054 \mathrm{~g} / 100 \mathrm{~g}$ ) acids. These results might indicate some specificity in lipase activity under freezing/thawing conditions that favour the release of unsaturated chains. Indeed, lipases from various microorganisms have shown activity at freezing temperatures $\left(-7^{\circ} \mathrm{C},-18^{\circ} \mathrm{C}\right.$ and even $\left.-29^{\circ} \mathrm{C}\right)$ with different specificities for $\mathrm{FA}$, with the rate of lipolysis in frozen substrates being directly related to their degree of unsaturation (Alford and Pierce, 1961). This possible typoselectivity of lipolysis is probably linked to the liquid or solid state of TAGs at reaction temperature. Indeed, the liquid state of TAG molecules allows lipase activity, while solid TAGs are less easily hydrolysed. At chilling temperature $\left(5^{\circ} \mathrm{C}\right)$ compared to room temperature, lipases preferentially hydrolysed TAGs bearing unsaturated fatty acids, such as POO and OOO (Sambanthamurthi et al., 1991). Our results apparently contradicted this assumption: the percentages of TAGs bearing oleic acid, i.e. OOL, POL, OOO, POO and SOO, were found to increase from Day 1 to Day 9, at the expense of PPL, PPO, PPP, PSO, PPS and SSO (Tab. 3). However, such an apparent contradiction can be explained by the highest lipolysis on Day $1(44.75 \pm 0.80 \%)$ compared to Day $9(26.08 \pm 0.05 \%)$, which explained why the highest pool of preserved TAGs containing unsaturated lipids was present on Day 9.

\subsection{Lipid oxidation and correlation with FFA contents}

In the second set of experiments, the concentrations in linoleic and linolenic acids remained steady in CPO extracted from unfrozen fruits (Tab. 1) suggesting a limited oxidation of polyunsaturated fatty acids during fruit storage at room temperature. In parallel, very low peroxide and anisidine values were recorded, whatever the storage time, though 
Table 5. Carotenoid ( $\beta$-carotene eq.), tocopherol and tocotrienol contents $(\mu \mathrm{g} / \mathrm{g})$ of crude palm oils extracted from different selected palms, either one day after harvest (D1) or after fruit freezing on D1.

\begin{tabular}{lll}
\hline Components $(\mu \mathrm{g} / \mathrm{g}$ oil $)$ & Oil obtained after direct extraction of palm fruits & Oil obtained after frozen storage of palm fruits \\
\hline Carotenoids & $734.7 \pm 4.7$ & $1108.5 \pm 0.4$ \\
Total tocopherols + tocotrienols & $714.7 \pm 4.4$ & $427.3 \pm 10.7$ \\
\hline
\end{tabular}

Results are expressed as means \pm standard deviations $(n=3)$.

a slight increase in both parameters occurred, which was highlighted by the increase in TOTOX $(2 \mathrm{PV}+1 \mathrm{AV})$, considered as a more reliable marker of the main phases of lipid oxidation (Tab. 4). However, PV and AV remained below the threshold value generally considered as acceptable for edible oils $\left(<5\right.$ to $15 \mathrm{meq} \mathrm{O}_{2} / \mathrm{kg}$ and $<20$ for $\mathrm{PV}$ and $\mathrm{AV}$, respectively) as reported by Viau et al. (2016). PV was higher in oil extracted from frozen fruits, but it also remained at very low levels and steady (around 2 meq $\mathrm{O}_{2} / \mathrm{kg}$ oil), whatever the spikelet storage time (Tab. 4). In contrast, AV exceeded the above-mentioned limit. PV indicates the presence of hydroperoxides, the primary products of lipid oxidation. CPO extraction includes several heating steps, which probably led to the decomposition of hydroperoxides and the generation of secondary products of oxidation, including the aldehydes, which are probed by the anisidine test. This could explain why low PV values were accompanied by high AV values in CPO extracted from frozen fruits. AV decreased with the fruit storage time. Consequently, the TOTOX value, which was higher for frozen fruits than after direct extraction, also decreased from 53 to 30 as a function of the duration of fruit storage at room temperature. These results indicate that lipid oxidation took place during freezing, frozen storage and thawing of the fruits, but to a lesser extent during storage at room temperature. Lipid oxidation can be linked to the presence of the FFAs produced during fruit ripening (Fig. 2). Free fatty acids are recognized as promoting lipid oxidation in both homogeneous (meaning oils such as palm oil) and heterogeneous systems (Choe and Min, 2006; Waraho et al., 2011; De Leonardis et al., 2016). Very interestingly, PV, AV and TOTOX were highly correlated with FFA content, whatever the processing conditions, as indicated by very significant Pearson correlation coefficients $(p<0.01)$ of 0.953 , 0.999 and 0.998 , respectively. This result highlights the prooxidative effect of FFA produced during palm fruit postharvest treatments and sheds light on potentially high oxidation levels in crude palm oils produced in artisanal, small-scale workshops, despite their high concentrations of antioxidants, such as tocopherols and carotenoids.

\subsection{Tocopherols, tocotrienols and carotenoids in crude palm oil}

Total tocol contents of the oils are reported in Table 5. Alpha, $\beta$-, and $\gamma$-tocopherols and $\alpha-, \gamma$ - and $\delta$-tocotrienols were tentatively identified in CPO. $\gamma$-Tocotrienol was by far the major component. Carotenoids were quantified by visible spectrophotometry, and expressed as equivalent $\beta$-carotene. Indeed, $\beta$-carotene is the major carotenoid in palm oil, along with smaller amounts of $\alpha$-carotene and several minor carotenoids (Zou et al., 2012; Ribeiro et al., 2018). The carotenoid, and the tocopherol plus tocotrienol (total tocols) contents of the oils extracted from frozen or unfrozen fruits processed on Day 1 after harvest differed greatly, with larger amounts of carotenoids, but smaller amounts of tocols after freezing (Tab. 1). The most plausible explanation for these differences lies in the genetic diversity of the different selected palms from which bunches were harvested. This tallied with the above highlighted differences in fatty acid and TAG compositions of the oils derived from both treatments, mainly attributed to the diversity of the selected palms. A second hypothesis is that oxidation linked to freezing treatment and frozen storage (Tab. 4) led to losses in antioxidants, such as tocols. This explanation is unlikely because the oils prepared from frozen fruits contained larger amounts of carotenoids than the oils prepared from unfrozen fruits. Lastly, freezing could have favoured the extraction of carotene due to cell disorganisation, but not that of tocopherols and tocotrienols. These differences in the amounts and compositions of the selected lipophilic micronutrients in the frozen and unfrozen samples likely due to the genetic diversity of the fruits make it difficult to assess directly how freezing/frozen storage/ thawing affected oil composition. To compare the changes in the lipophilic micronutrients induced by storage at room temperature in oils from unfrozen and frozen fruits, the data initially expressed as $\mu \mathrm{g} / \mathrm{g}$ oil were converted into percentages of the carotenoid or tocol contents of the oils one day after harvest, for unfrozen and frozen samples separately (Fig. 3).

$\mathrm{CPO}$ which was directly extracted from unfrozen samples contained more or less constant amounts of tocols, whatever the time post-harvest (Fig. 3A). In contrast, the carotenoid content decreased regularly and significantly. Basyuni et al. (2017) also reported a decrease in carotene content when palm fruits were stored before processing. During frying of red palm olein, $\beta$-carotene was also depleted more rapidly than $\alpha$-tocopherol and tocotrienols, with carotene protecting the tocols by sacrificial regeneration, with both antioxidants developing synergistic actions in delayed development of lipid oxidation in palm olein (rancimat test) and in a model liposome system (Schroeder et al., 2006). The small increase in oxidation level (Tab. 4) simultaneously observed with carotene loss in our experiment could indicate that the latter was linked to the development of lipid oxidation, in its very early stages.

In the oil extracted from frozen fruits, the total amount of carotene and tocopherols plus tocotrienols decreased with the storage time at room temperature, with a sharp drop between Day 5 and Day 7 (Fig. 3B). Individuals tocols showed similar behaviours (results not shown). These results could indicate that losses of antioxidant micronutrients are favoured in frozen fruits due to the damage caused to the cell structure of the 


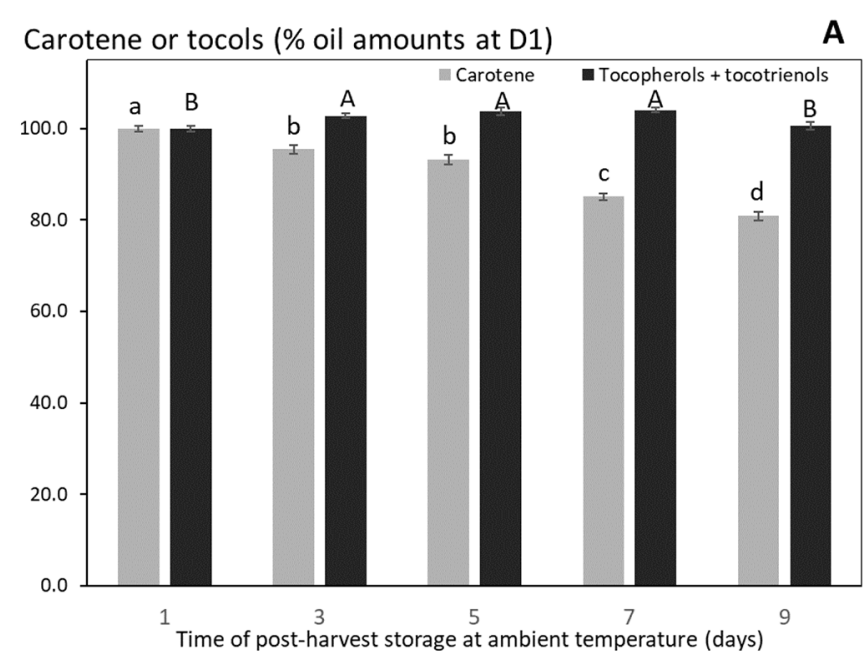

Carotene or tocols (\% oil amounts at D1)

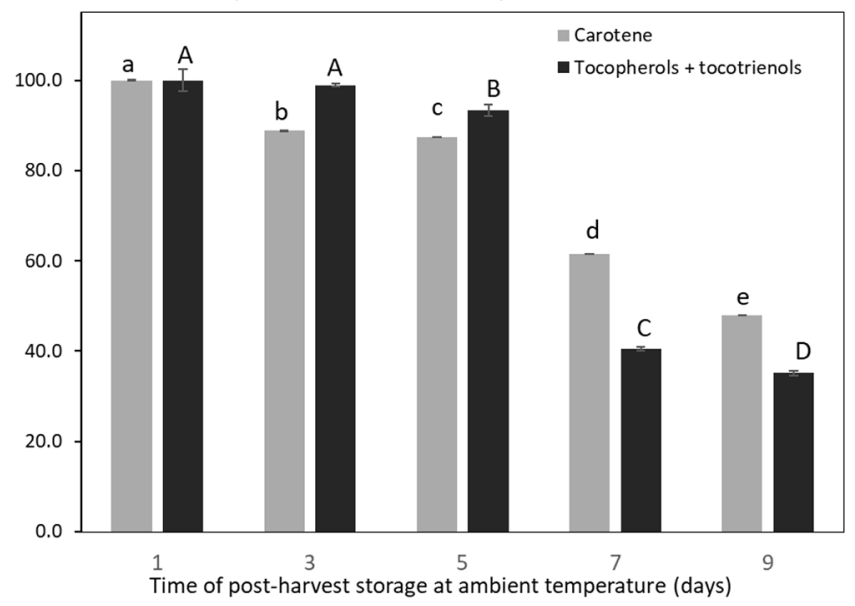

Fig. 3. Variation in tocopherol + tocotrienol and carotene contents of CPOs extracted at different times after harvest (A), or after freezing of the stored fruits (B), expressed as percentages of the amounts measured in the oils extracted on day 1 . Mean \pm standard error of triplicates. Bars superscripted with different letters in the same group differ significantly by Tukey's test $(p<0.05)$.

fruits. (Sambanthamurthi et al., 1991) did not observe any variation in carotene content for palm fruits kept overnight at $-20^{\circ} \mathrm{C}$, as compared to fruits kept at room temperature $\left(28^{\circ} \mathrm{C}\right)$, although these authors observed a $39 \%$ decrease in carotene content for fruits stored overnight at $5{ }^{\circ} \mathrm{C}$. According to (Park, 1987), thawing conditions expose plant material to light, temperature, oxygen and loss of moisture, while catalytic enzymes (lipoxygenase, cytochrome C) are activated, which might enhance the degradation of carotene through free radical mechanisms. In our case, as already noted, AV and TOTOX were quite high in analysed oils. They decreased significantly with the duration of fruit storage at room temperature (Tab. 4). Pearson's correlation parameters between TOTOX or AV and total tocols ( $\%$ of amount on D 1$)$ or $\%$ carotenes $(\%$ of amount on D1) were low and not significant. As mentioned above, the loss of carotenes and tocopherols + tocotrienols probably partly protected the unsaturated fatty acids of palm oil against oxidation.

\section{Conclusions}

Our results confirmed that lipases were activated by freezing/thawing, with the activity levelling off when the fruits were kept for several days at room temperature before freezing (product inhibition, or effect of freezing/thawing cycles). Such a release of free fatty acids promoted the development of lipid oxidation, as revealed by the formation of secondary oxidation products. The carotene content in oil decreased for fruits stored at room temperature and that decrease was amplified by freezing/thawing. In contrast, tocopherols and tocotrienols were found stable at room temperature, but decreased substantially with freezing. The recorded losses in antioxidant micronutrients could be linked to their protective role against lipid oxidation.

During artisanal, at small-scale palm oil extraction process, palm fruits can be stored post-harvest at room temperature to achieve the best oil yield for a targeted use, with the required oil composition, and preserve the nutritional quality of the oil. According to our results, 3 days of post-harvest storage facilitate fruit recovery and CPO extraction, while limiting CPO lipolytic and oxidative degradation. For post-harvest storage times longer than 5 days, the risk of impairment of oil quality increased considerably.

By combining storage at room temperature and freezing/ thawing of palm fruits, crude palm oils exhibiting a wide range of FFA contents can be easily produced in the laboratory. These oils can be a valuable tool for assessing CPO functional properties (i.e. emulsifying properties) and the sensory perception of CPO by local consumers, and for determining desirable FFA contents for crude palm oils produced by artisanal, small-scale extraction units. Our study also highlighted that a careful control of lipid oxidation during extraction is required to ensure CPO quality. More generally, post-harvest storage of palm fruits at room temperature, and freezing/thawing, can be applied to generate the best oil yield for a targeted use, or the appropriate oil composition.

\section{Abbreviations}

$\begin{array}{ll}\text { CPO } & \text { Crude palm oil } \\ \text { FAME } & \text { Fatty acid methyl esters } \\ \text { FFA } & \text { Free fatty acids } \\ \text { FFB } & \text { Fresh fruit bunches } \\ \text { TAG } & \text { Triacylglycerol } \\ \text { TFA } & \text { Total fatty acids }\end{array}$

Acknowledgements. This work was supported by the INRACIRAD GloFoodS metaprogramme through the funding of the Qualipalm-P6 project. DN benefited from several grants for travelling, and living allowances in France provided by CIRAD and by SCAC (Service de Coopération et d'Action Culturelle) at the French Embassy in Yaoundé, Cameroon [Project 0185CMR B15 0061] (https://cm.ambafrance.org/ Bourses-du-gouvernement-Français). 
We gratefully acknowledge Michèle Viau and Lucie Ribourg (INRA-BIA, Nantes, France) for their very useful help in fatty acid, TAG, tocopherol/tocotrienol and carotenoid analyses.

\section{References}

Abigor DR, Opute FI, Opoku AR, Osagie AU. 1985. Partialpurification and some properties of the lipase present in oil palm (Elaeis guineensis) mesocarp. J Sci Food Agric 36: 599-606.

Afnor. 1981a. NF T60-204 Détermination de l'indice d'acide. In: Afnor, ed. Recueil de normes françaises des corps gras graines oléagineuses produits dérivés, 2nd ed. Paris (France), pp. 119-123.

Afnor. 1981b. NF T 60-233 Préparation des esters méthyliques d'acides gras. In: Afnor, ed. Recueil de normes françaises des corps gras graines oléagineuses produits dérivés, 2nd ed. Paris (France), pp. 73-79.

Afnor. 1981c. NF T 60-220 Détermination de l'indice de peroxyde. In : Afnor, ed. Recueil de normes françaises des corps gras graines oléagineuses produits dérivés, 2nd ed. Paris (France), pp. 126128.

Alasnier C, Meynier A, Viau M, Gandemer G. 2000. Hydrolytic and oxidative changes in the lipids of chicken breast and thigh muscles during refrigerated storage. J Food Sci 65: 9-14.

Alford JA, Pierce DA. 1961. Lipolytic activity of microorganisms at low and intermediate temperatures. 3. Activity of microbial lipases at temperatures below 0 degree C. J Food Sci 26: 518-524.

Balls AK, Tucker IW. 1938. Activity of lipase at low temperature. Ind Eng Chem 30: 415-16.

Basyuni M, Amri N, Putri L, Arifiyanto D, Syahputra I. 2017. Characteristics of fresh fruit bunch yield and the physicochemical qualities of palm oil during storage in North Sumatra, Indonesia. Indonesian J Chem 17: 182-90.

Cadena T, Prada F, Perea A, Romero HM. 2013. Lipase activity, mesocarp oil content, and iodine value in oil palm fruits of Elaeis guineensis, Elaeis oleifera, and the interspecific hybrid o $\times \mathrm{g}(E$. Oleifera $\times$ E. Guineensis). J Sci Food Agric 93: 674-80.

Cassiday L. 2017. Red palm oil. INFORM Int News Fats Oils Related Mater 28: 6-10.

Cheyns E, Rafflegeau, S. 2005. Family agriculture and the sustainable development issue: Possible approaches from the African oil palm sector: The example of Ivory Coast and Cameroon. OCL 12: 111120.

Cheyns E, Lamine C, Bricas N. 2006. L'huile de palme rouge au Cameroun et en Côte d'Ivoire. Etude de cas. In: Coordination et qualité dans les filières agricoles du sud. Montpellier (France) : Cahier de recherche UMR MOISA, AgroM, CIHEAM-IAMM, CIRAD, INRA, IRD, pp. 69-88.

Choe E, Min DB. 2006 Mechanisms and factors for edible oil oxidation. Compr Rev Food Sci Food Saf 5(4): 169-186.

Chong CL, Sambanthamurthi R. 1993. Effects of mesocarp bruising on the rate of free fatty-acid release in oil palm fruits. Int Biodeterior Biodegr 31: 65-70.

Cochard B, Adon B, Kouame RK, Durand-Gasselin T, Amblard P. 2001. Advantages of improved commercial palm oil (Elaeis guinensis jacq.) seeds. OCL 8: 654-58.

Corley RHV, Tinker PBH. 2016. The Oil palm, 5th ed. WileyBlackwell. ISBN: 978-1-405-18939-2. https://doi.org/10.1002/ 9781118953297.

De Leonardis A, Cuomo F, Macciola V, Lopez F. 2016 Influence of free fatty acid content on the oxidative stability of red palm oil. RSC $A d v$ 6(103): 101098-101104. https://doi.org/10.1039/c6ra16953h.
Domonhedo H, Cros D, Nodichao L, Billotte N, Ahanhanzo C. 2018. Reduction of acidity in mature oil palm (Elaeis guineensis jacq.) fruits: Stakes and oil quality improvement. A review. Biotechnol Agron Soc Environ 22: 54-66.

Dong SN, Xia H, Wang F, Sun GJ. 2017. The effect of red palm oil on vitamin A deficiency: a meta-analysis of randomized controlled trials. Nutrients 9: 15. https://doi.org/10.3390/nu9121281.

Eggins HOW, Coursey DG. 1968. Industrial significance of biodeterioration of oilseeds. Int Biodeterior Bull 4: 29-38.

Fogang AR, Kansci G, Viau M, et al. 2017. Lipid and amino acid profiles support the potential of Rhynchophorus phoenicis larvae for human nutrition. J Food Compos Anal 60: 64-73.

Gee PT. 2007 Analytical characteristic of crude and refined palm oil and fractions. Eur J Lipid Sci Technol 109: 373-379. https://doi. org/10.1002/ejlt.200600264.

Genot C. 2000. Congélation et qualité de la viande. Paris (France) : INRA Ed, 98 p. ISBN: 2-7380-0931-X; ISSN:1-1150-3912.

Gibon V, De Greyt W, Kellens M. 2007. Palm oil refining. Eur J Lipid Sci Technol 109: 315-35.

Hayes KC, Khosla P. 2007. The complex interplay of palm oil fatty acids on blood lipids. Eur J Lipid Sci Technol 109: 453-64.

Henderson J, Osborne DJ. 1991. Lipase activity in ripening and mature fruit of the oil palm-Stability in vivo and in vitro. Phytochemistry 30: 1073-78.

Hiol A, Jonzo MD, Rugani N, Druet D, Sarda L, Comeau LC. 2000. Purification and characterization of an extracellular lipase from a thermophilic Rhizopus oryzae strain isolated from palm fruit. Enzyme Microb Technol 26: 421-30.

ISO. 2006. Animal and vegetable fats and oils. Determination of anisidine value. International Standard ISO 6885, $7 \mathrm{p}$.

Kabri TH, Meynier A, Bontemps D, et al. 2013. Formulation of submicron emulsions containing docosahexaenoic acid esterified in triacylglycerols or phospholipids. Eur J Lipid Sci Technol 115: 1294-308.

Kansci G, Genot C, Kamdem AM, et al. 2003. Composition and oxidation level of some vegetable oils consumed in Cameroon, determined by classical and mid infrared spectroscopic methods. Sciences des Aliments 23: 425-41.

Lai O-M, Tan CP, Akoh CC. 2012. Palm oil: Production, processing, characterization, and uses. Urbana, IL: AOCS Press.

Loganathan R, Subramaniam KM, Radhakrishnan AK, Choo YM, Teng KT. 2017. Health-promoting effects of red palm oil: Evidence from animal and human studies. Nutr Rev 75: 98-113.

May CY, Nesaretnam K. 2014. Research advancements in palm oil nutrition. Eur J Lipid Sci Technol 116: 1301-15.

Mba ARF, Kansci G, Viau M, et al. 2018. Growing conditions and morphotypes of african palm weevil (Rhynchophorus phoenicis) larvae influence their lipophilic nutrient but not their amino acid compositions. J Food Compos Anal 69: 87-97.

Mohan TCK, Mohankumar C. 2004. Biochemical changes in the cell wall of oil palm fruit mesocarp (Elaeis guineensis jacq) during development and post-harvest storage. J Food Sci TechnolMysore 41: 191-93.

Mohankumar C, Arumughan C, Raj RK. 1990. Histological localization of oil palm fruit lipase. J Am Oil Chem Soc 67: 665-69.

Monde AA, Michel F, Carbonneau M-A, et al. 2009 Comparative study of fatty acid composition, vitamin $\mathrm{E}$ and carotenoid contents of palm oils from four varieties of oil palm from Côte d'Ivoire. J Sci Food Agric 89: 2535-2540. https://doi.org/10.1002/jsfa.3740.

Montoya C, Cochard B, Flori A, et al. 2014. Genetic architecture of palm oil fatty acid composition in cultivated oil palm (Elaeis guineensis jacq.) compared to its wild relative e. Oleifera (H.B. 
K.) cortés. Plos One 9(6): 13.e101628. https://doi.org/10.1371/ journal.pone. 0101628 .

Morcillo F, Cros D, Billotte N, et al. 2013. Improving palm oil quality through identification and mapping of the lipase gene causing oil deterioration. Nat Commun 4: 2160. https://doi.org/10.1038/ ncomms 3160 .

Morrison WR, Smith LM. 1964. Preparation of fatty acid methyl esters and dimethylacetals from lipids with boron fluoridemethanol. J Lipid Res 5: 600-08.

Ngando Ebongue GF, Dhouib R, Carriere F, Zollo PHA, Arondel V. 2006. Assaying lipase activity from oil palm fruit (Elaeis guineensis jacq.) mesocarp. Plant Physiol Biochem 44: 611-17.

Ngando Ebongue GF, Koona P, Nouy B, et al. 2008. Identification of oil palm breeding lines producing oils with low acid values. Eur $J$ Lipid Sci Technol 110: 505-09.

Ngando Ebongue GF, Mpondo Mpondo EA, Dikotto Ekwe EL, Koona P. 2011. Assessment of the quality of crude palm oil from smallholders in Cameroon. J Stored Prod Postharv Res 52-58.

Noh A, Rajanaidu N, Kushairi A, et al. 2002. Variability in fatty acid composition, iodine value and carotene content in the MPOB oil palm germplasm collection from Angola. JOil Palm Res 14: 18-23.

Oguntibeju OO, Esterhuyse AJ, Truter EJ. 2009. Red palm oil: Nutritional, physiological and therapeutic roles in improving human wellbeing and quality of life. Br J Biomed Sci 66: 216-22.

Oil world. 2018. Statistics. Hamburg, G: ISTA Mielke Gmbh. Available from https://www.oilworld.biz/t/publications/data-base (last consult: 2018/06/15).

Olalusi PAP, Oni PIO, Ajewole PO. 2017. Effect of some processing parameters on quality of palm oil. Int J Innov Sci Eng Technol 4: 146-153. ISSN (Online) 2348-7968.

Ordway EM, Naylor RL, Nkongho RN, Lambin EF. 2017. Oil palm expansion in Cameroon: Insights into sustainability opportunities and challenges in Africa. Global Environ Change-Human Policy Dimensions 47: 190-200.

Ordway EM, Naylor RL, Nkongho RN, Lambin EF. 2019. Oil palm expansion and deforestation in Southwest Cameroon associated with proliferation of informal mills. Nat Commun 10: 114. https:// doi.org/10.1038/s41467-018-07915-2.

Park YW. 1987. Effect of freezing, thawing, drying, and cooking on carotene retention in carrots, broccoli and spinach. J Food Sci 52: $1022-25$.

Poku K. 2002. Small-scale palm oil processing in Africa. Roma, I: FAO Agricultural Services Bulletin.

Rafflegeau S, Michel-Dounias I, Tailliez B, Ndigui B, Papy F. 2010. Unexpected $\mathrm{N}$ and $\mathrm{K}$ nutrition diagnosis in oil palm smallholdings using references of high-yielding industrial plantations. Agron Sustain Develop 30: 777-87.
Rafflegeau S, Nanda D, Genot C. 2018. Artisanal mills and local production of palm oil by smallholders. In: Rival A, ed. Achieving sustainable cultivation of oil palm. Volume 2: Diseases, pests, quality and sustainability. Cambridge (UK): Burleigh Dodds Science Publ., 29 p. http://dx.doi.org/10.19103/ AS.2017.0018.36

Rébéna A, Rafflegeau S, Kansci G, Nanda D, Genot C. 2019. Enquêtes sur la consommation, la perception et les utilisations de l'huile de palme rouge chez les ménagères et restauratrices de Yaoundé, Cameroun. Cahiers d'Agriculture 28: 27-33. https:// doi.org/10.1051/cagri/2019027.

Ribeiro JAA, Almeida ES, Neto BAD, Abdelnur PV, Monteiro S. 2018. Identification of carotenoid isomers in crude and bleached palm oils by mass spectrometry. LWT-Food Sci Technol 89: 631637.

Sambanthamurthi R, Let CC, Cheang OK, Huat YK, Rajan P. 1991. Chilling-induced lipid hydrolysis in the oil palm (Elaeis guineensis) mesocarp. J Experiment Bot 42: 1199-205.

Schroeder MT, Becker EM, Skibsted LH. 2006. Molecular mechanism of antioxidant synergism of tocotrienols and carotenoids in palm oil. J Agric Food Chem 54: 3445-3453.

Sisla RV, Erickso MC, Shewfell R. 1997. Quality deterioration in frozen foods associated with hydrolytic enzyme activities. In: Erickson M, Hung Y-C, eds. Quality in frozen food. Dordrecht (Germany): Springer Science \& Business Media, pp. 101-110.

Tagoe SMA, Dickinson MJ, Apetorbor M. 2012. Factors influencing quality of palm oil produced at the cottage industry level in Ghana. Int Food Res $J$ 19: 271-78.

Tang MM, Xia QY, Holland BJ, Wang H, Zhang YF, Li R, Cao HX. 2017. Effects of different pretreatments to fresh fruit on chemical and thermal characteristics of crude palm oil. J Food Sci 82: 2857-2863.

Viau M, Genot C, Ribourg L, Meynier A. 2016. Amounts of the reactive aldehydes, malonaldehyde, 4-hydroxy-2-hexenal, and 4hydroxy-2-nonenal in fresh and oxidized edible oils do not necessary reflect their peroxide and anisidine values. Eur J Lipid Sci Technol 118: 435-444. https://doi.org/10.1002/ ejlt.201500103.

Waraho T, McClements DJ, Decker EA. 2011 Impact of free fatty acid concentration and structure on lipid oxidation in oil-in-water emulsions. Food Chem 129: 854-859.

Zou Y, Jiang Y, Yang T, Hu P, Xu X. 2012. Minor constituents of palm oil: characterization, processing, and application. In: Lai O-M, Tan C-P, Akoh CC, eds. Palm Oil production, processing characterization, and uses. Urbana, IL (USA): AOCS Press, Chap. 16, pp. 471-526.

Cite this article as: Nanda D, Kansci G, Rafflegeau S, Bourlieu C, Ngando Ebongue G, Genot C. 2020. Impact of post-harvest storage and freezing of palm fruits on the extraction yield and quality of African crude palm oil extracted in the laboratory. $O C L 27: 52$. 